\section{The potential of using xylarium wood samples for wood density calculations: a comparison of approaches for volume measurement}

\author{
Maniatis $D^{(1)}$, Saint André $L^{(2-3)}$, Temmerman $M^{(4)}$, Malhi $Y^{(1)}$, \\ Beeckman $\mathrm{H}^{(5)}$
}

Wood specific gravity (WSG) is an important biometric variable for aboveground biomass calculations in tropical forests. Sampling a sufficient number of trees in remote tropical forests to represent the species and size distribution of a forest to generate information on WSG can be logistically challenging. Several thousands of wood samples exist in xylaria around the world that are easily accessible to researchers. We propose the use of wood samples held in xylaria as a valid and overlooked option. Due to the nature of xylarium samples, determining wood volume to calculate WSG presents several challenges. A description and assessment is provided of five different methods to measure wood sample volume: two solid displacement methods and three liquid displacement methods (hydrostatic methods). Two methods were specifically developed for this paper: the use of laboratory parafilm to wrap the wood samples for the hydrostatic method and two glass microbeads devices for the solid displacement method. We find that the hydrostatic method with samples not wrapped in laboratory parafilm is the most accurate and preferred method. The two methods developed for this study give close agreement with the preferred method $\left(r^{2}>0.95\right)$. We show that volume can be estimated accurately for xylarium samples with the proposed methods. Additionally, the WSG for 53 species was measured using the preferred method. Significant differences exist between the WSG means of the measured species and the WSG means in an existing density database. Finally, for 4 genera in our dataset, the genus-level WSG average is representative of the species-level WSG average.

Keywords: Wood specific gravity, Aboveground biomass, Dry xylarium samples, Tropical forests, Congo basin forest

\footnotetext{
Introduction

Tropical deforestation and degradation are estimated to have released on the order of 1 $2 \mathrm{Pg} \mathrm{C} / \mathrm{yr}$ (15 - 35 percent of annual fossil fuel emissions) during the 1990s (Houghton 2005). A key technical challenge for the successful implementation of mechanisms that can help reduce emissions from deforestation and degradation is the reliable estimation of the aboveground biomass (AGB) in tropical forests. Reliable estimation of AGB depends on a number of sampling issues, including sampling of spatial variability, determination of forest structural allometry and determination of tree wood density, also known as wood specific gravity (WSG).

WSG is defined as the ratio of the oven-dry mass of a sample to the mass of a volume of water equal to the volume of the sample at a specific moisture content (ASTM International 2011) and is calculated by dividing the mass of a sample by its volume. Although mass is easy to determine, the volume determination is a less straightfor-
}

ward procedure. Moreover, sampling a sufficient number of trees for WSG to represent the species and size distribution in highly diverse tropical forests is time consuming and costly. For tropical regions, published data on wood specific gravity are frequently limited to a number of commercial timber species that only represent a fraction of the forest biomass.

On the other hand, there are collectively hundreds of thousand wood samples held in xylaria (botanical collection with wood samples from lignified plants (Beeckman 2008) around the world, spanning wide geographic areas including the tropics and many tens of thousands of species (Stern 1988).

Given the above, this paper focuses on WSG by: (1) exploring the possibility of obtaining the WSG of tropical tree species using xylaria samples; we examined the accuracy and practicality of five different methodologies, two solid displacement methods and three liquid displacement methods (of which two were specifically designed and
(1) Environmental Change Institute, School of Geography and the Environment, Dyson Perrins Building, South Parks Road, OX1 3QY Oxford (UK); (2) CIRAD, UMR Eco \& Sols, Ecologie Fonctionnelle, Biogéochimie des Sols \& Agroécosystèmes, place Viala, F34060 Montpellier (France); (3) INRA, UR BEF - Biogéochimie des Ecosystèmes Forestiers, F-54280, Champenoux (France); (4) Walloon Agricultural Research Centre (CRA-W), chaussée de Namur 146, B-5030 Gembloux (Belgium); (5) Laboratory for Wood Biology and Xylarium, Royal Museum for Central Africa, Leuvense Steenweg 13, B-3080 Tervuren (Belgium)

\section{(a) Danae Maniatis}

(danae.maniatis@gmail.com)

Received: Sep 15, 2010 - Accepted: May 16, 2011

Citation: Maniatis D, Saint André L, Temmerman M, Malhi Y, Beeckman H, 2011. The potential of using xylarium wood samples for wood density calculations: a comparison of approaches for volume measurement. iForest 4: 150-159 [online 2011-08-11] URL:

http://www.sisef.it/iforest/ show.php? id $=575$

developed for the purposes of this paper); (2) measuring wood sample volume for the purpose of calculating WSG; and (3) providing a preliminary ecological assessment of WSG for 53 species in the Congo Basin in which we illustrate inter-individual variation in WSG, make a comparison of the WSG values of the species we measured to an existing wood density database, and examine genus-level WSG representativeness for species-level WSG.

\section{Background}

There exists a great diversity of tropical woods with densities ranging from 0.1 ("light woods") to 1.2 ("heavy woods") $\mathrm{g} / \mathrm{cm}^{3}$. WSG is considered as a crucial wood property affecting the properties and value of both solid and fibrous wood products (Pliura et al. 2007). As a good predictor of mechanical properties of wood, it is often viewed in relation to support against gravity, snow, wind and other environmental forces (Hacke et al. 2001).

Furthermore, WSG is an important factor for AGB estimates (Baker et al. 2004, Nogueira et al. 2005, Slik 2006). The most important predictors of $\mathrm{ABG}$ of a tree are its trunk diameter, wood specific gravity, total height and forest type (Chave et al. 2005). The most important source of error in AGB estimation is currently related to the choice of allometric model (Chave et al. 2005). However, ignoring variations in WSG can 
result in mediocre overall prediction of the ABG biomass stand (Baker et al. 2004) greenhouse-gas emissions (Nogueira et al. 2005).

With regards to forest dynamics, WSG is related to the growth and mortality rates of a tree species (Muller-Landau 2004) and provides information on life-history strategies of tree species (King et al. 2005). Additionally, WSG is a strong indicator of ecological succession stages with the pioneer species having greater variation and being less dense than climax species (Wiemann \& Williamson 2002, Muller-Landau 2004). Severa studies have shown that wood density is positively related to drought resistance in tropical trees (Hacke et al. 2001, Slik 2004) and shrubs (Hacke et al. 2000). Given the above, it is indeed unfortunate to find that the wood density of many tropical trees remains unknown (Slik 2006).

As density is one of the most important parameters of wood quality, its measuremen methods have been the subject of general publications on the physical properties of wood and moisture relations (cf. Simpson 1993, Simpson \& TenWolde 1999) and specific measurement methods papers, such as: medical CAT-scan imaging for very small samples (Lindgren 1991); stereometric method (Rabier et al. 2006); mercury method (cf. Dutilleul et al. 1998); microdensitometer techniques (Cameron et al. 1959, Polge 1966, Mothe et al. 1998, Bergsten et al 2001); basic density (dry weight / wet volume) for freshly collected samples for conversion to AGB (Fearnside 1997); vibrational spectroscopy such as near infrared reflectance (NIR - Via et al. 2003, Via et al 2005), Fourier Transform Infrared (FTIR) spectroscopic bands (Via et al. 2011) and Diffuse Reflectance Mid-Infrared Fourier transform (DRIFT-MIR - Nuopponen et al 2006).

The above methods all have several advantages and disadvantages related to them. The main disadvantages related to some of the methods described above are: high cost; inability to take the xylarium samples out of the place they are stored (building); the fact that most samples do not have uniform or regular geometrical shapes; that the cutting of sub-samples is not allowed; and the phasing out of mercury in many industries. What is clear is the need to develop feasible, practical, quick and cheap non-destructive methods to determine the volume of xylarium samples.

\section{Material and methods}

\section{The wood sample collection}

As a case study, we chose to focus on the major tropical forest region with perhaps the greatest deficit of ecological information: the Congo Basin Forest. The xylarium of the museum for central Africa in Tervuren (Belgium) holds the largest collection of wood samples for the Congo Basin Forest in the world (Beeckman 2007). Some samples have relatively precise descriptions of the trees (estimated height, large or small tree) and locations from where they were collected. There are also several samples per species, genus and family, making it possible to conduct a detailed study on the across- and within-taxon variability of WSG. The xylarium also holds wood samples of what are now rare and protected species that could be difficult to collect today.

\section{Particularities of using xylarium samples}

Due to the long-term mission of the xylarium, samples are dry and have to remain in their original condition, i.e., the structural and chemical state of the sample must be preserved. Determining the WSG of such samples presents several difficulties. First, the format of the samples is not standard (e.g., irregular shapes, small planks, book shaped planks and circular pieces of wood). Second, it may not be allowed to cut pieces off the samples. Third, the samples may not be allowed to be covered in paraffin, wetted or treated with any chemical that may damage the sample, both in appearance and in any physical or molecular way. Last, the samples may perhaps not leave the designated area or be transported elsewhere for further studies.

\section{Terminology}

Of all the physical properties of wood, WSG was the first to be examined systematically. An overview of the data from $18^{\text {th }}$ and beginning of $19^{\text {th }}$ century has been given by Chevandier \& Wertheim (1848) in Kollmann (1951). We employ the terminology provided by the American Society for Testing and Materials (ASTM) specific gravity for wood can be defined as the ratio of the oven-dry mass of a sample to the mass of a volume of water equal to the volume of the sample at a specific moisture content (ASTM International 2011). Given that both the mass and, below the fibre saturation point, volume of wood vary with the amount of moisture contained in the wood, specific gravity as applied to wood is an indefinite quantity unless the conditions under which it is determined are clearly specified. The specific gravity of wood is based on the ovendry mass, yet the volume may be that in the oven-dry, partially dry or green condition (ASTM International 2011).

\section{Sample selection and preparation for volume assessment}

Two size categories of wood samples were selected: samples under $10 \times 10 \mathrm{~cm}$ crosssectional area and samples above $10 \times 10 \mathrm{~cm}$ (hereafter referred to as "small" and "large" samples, respectively). The samples are of irregular shapes and sizes with varying degrees of surface smoothness. One hundred small samples were selected of 24 different species. For the large samples, 18 samples were selected of 15 different species.

To reach oven-dry mass, samples were dried in an oven for 48 hours: 2 hours at 60 ${ }^{\circ} \mathrm{C}, 4$ hours at $80{ }^{\circ} \mathrm{C}$ and 42 hours at $103{ }^{\circ} \mathrm{C}$ to achieve constant weight. Temperature was increased gradually to minimise the risk of cracking the samples. Samples were weighed immediately after being taken out of the oven. The moisture content of the samples held in the xylarium before oven-drying (eqn. 1) was 8 percent. Samples under $2.1 \mathrm{~g}$ were weighed to the nearest $0.01 \mathrm{~g}$ while samples above $2.1 \mathrm{~g}$ were weighed to the nearest $0.1 \mathrm{~g}$ due to the limitations of the electronic balances used (eqn.1):

$$
M C=\frac{\left(m_{g}-m_{o d}\right)}{m_{o d}} \cdot 100
$$

where $m_{\mathrm{g}}$ is the mass of the wood sample as held in the xylarium and $m_{\text {od }}$ is the oven dry mass of the sample (attained after the oven drying and reaching constant mass). Volume measurements were done after the samples were oven dried and hence we measured an oven-dry WSG.

\section{Sample selection for ecological assess- ment}

The sample selection for a preliminary ecological assessment focused on the regional scale of the Congo Basin Forest. Some 976 samples from 53 species were measured. Species were selected based on the following criteria: (1) each species needed to have a minimum of ten samples that could be measured; and (2) each species had to occur in more than one region of the Congo Basin forest.

A comparison was made between the species means for the measured species and the means of the same species found in the Global Wood Density Database (GWDD Zanne et al. 2009) using a two-sample $t$-test assuming unequal variances at a five percent significance level. In order to evaluate whether or not genus-level WSG averages were representative of species-level WSG averages, a nested analysis of variance (ANOVA) was used.

\section{Liquid displacement methods}

These are methods based on Archimedes' principle: the volume of a sample is estimated by the mass of the volume that is displaced while the sample is submerged in liquid. The method used for this study is known as the hydrostatic method. In this method, the mass of the liquid which is displaced by the sample (oven-dry) is determined. A beaker is filled with water and 
placed on a digital balance. The balance is then re-zeroed. The sample is attached to an adjustable screw clamp (of which the volume is known and corrected for when submerged in the water), which is in turn attached to a vertically moving arm of a stand. The measured weight of displaced water equals the sample's volume (since water has a density of 1). The electronic balance was re-zeroed after every measurement. Three repetitions were made for each sample with the hydrostatic method. Three variations of the hydrostatic method were tested, using the same principle as described above and the same samples:

1. Samples wrapped in laboratory parafilm. The samples were weighed before coating and after coating them in laboratory parafilm. The difference in weight was subtracted from the volume of the sample. The disadvantage with laboratory parafilm wrapping is that it may trap air. Wrapping the wood samples in laboratory parafilm was developed specifically for the purposes of this paper. We used laboratory parafilm " $\mathrm{M}$ " which is water repellent and self-adhesive.

2. Samples not wrapped in laboratory parafilm. The volume of the sample was taken, the sample was dried off and the following repetition was made. Samples were not reweighed after each measurement to account for increase in weight.

3. Samples not wrapped in laboratory parafilm, with re-weighing the samples after each measurement in order to take account of increase in weight due to water absorption. The sample was weighed, the volume was of the sample was taken, the sample dried off, its weight taken, the difference in weight added to the volume of the sample (accounting for absorption) and the following repetition made.

\section{Solid displacement method}

These methods are based on the principle that solid materials are used to measure the volume of a given sample. Two solid displacement methods were tested:

1. Sand using a vibrating bed for compaction. For this method calibrated white sand was used. Sand was poured into a glass beaker until reaching a required volume (e.g., $100 \mathrm{ml}$ ). The beaker containing the sand was placed on a vibrating bed for 10 seconds to ensure compaction of the sand particles at a predefined volume (e.g., 100 $\mathrm{ml})$. In a second glass beaker recipient, some of the sand was poured in to cover the bottom of the recipient and subsequently the sample was placed on the sand. The rest of the sand was poured on top of the sample until the sand containing the sample reached the same initial volume $(100 \mathrm{ml})$ once again followed by compacting the sand on the vibrating bed. The re-

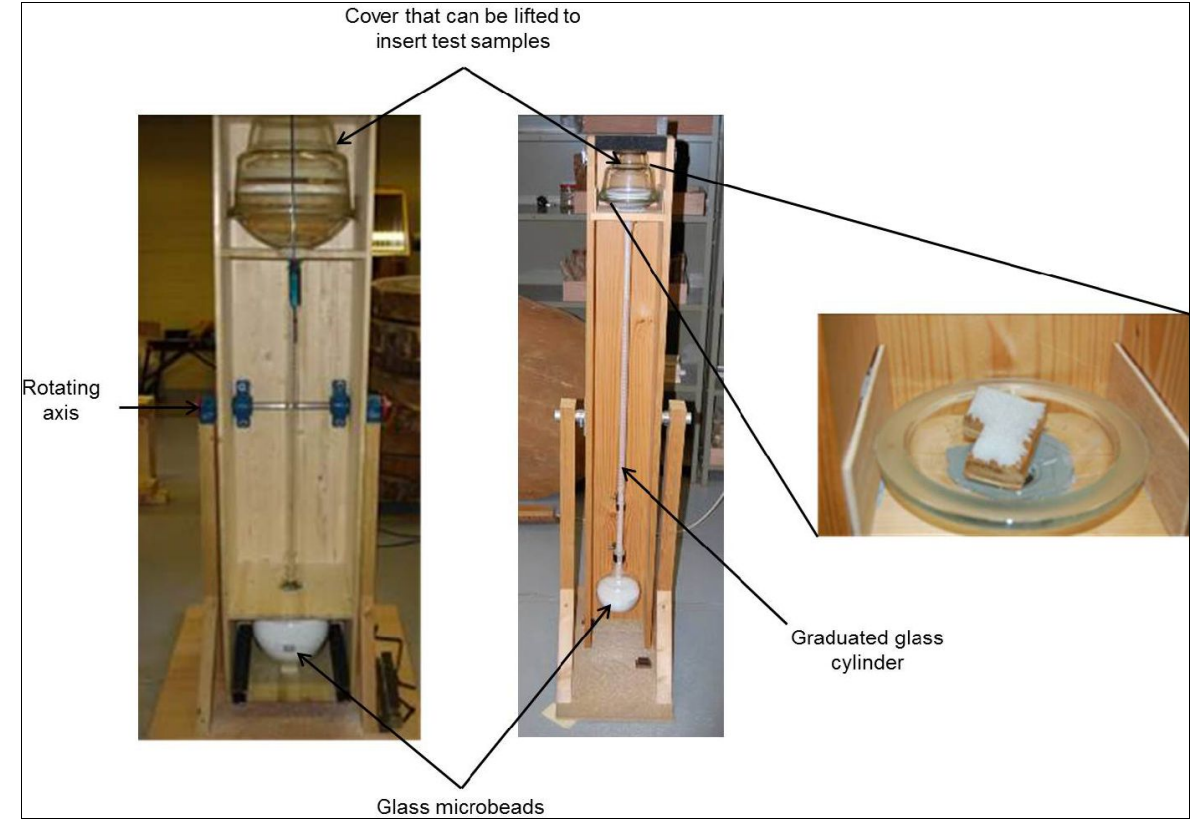

Fig. 1 - Glass micro-beads machines using height drop for compaction.

maining sand (again compacted) represents the volume of the sample. Two repetitions were made for each sample. A third measurement was taken if the difference between the two volume measurements was above 5 percent.

2. Glass microbeads using height drop for compaction. This machine was designed specifically for this study (Fig. 1). The concept of the machine is a semi-closed system of two glass recipients connected by a graduated cylinder (each $2 \mathrm{ml}$ graduation) held in a wooden structure. Two machines were built, one for small samples and one for larger samples. For the small samples, the volume of the graduated cylinder is $100 \mathrm{ml}$ and approximately $95 \mathrm{~cm}$ in vertical height. For the large samples, the graduated cylinder is $1000 \mathrm{ml}$ and the vertical height approximately $110 \mathrm{~cm}$. The method works like an hourglass. There is a constant amount of glass microbeads in the glass recipients (of 0.5 micrometers), the volume of which is read off the graduated cylinder (e.g., $20 \mathrm{ml})$. The system is rotated on its own axis and the glass micro-beads run into the second glass recipient. The sample is placed in the first glass recipient that can be opened. Once the sample is placed in the container, the system is turned around on its axis once more. The volume is once again read (e.g., $50 \mathrm{ml})$ and the difference in volume is the volume of the sample (e.g., in this example the volume equals to $30 \mathrm{ml}$ ). Two repetitions were made for each small sample. If the difference was greater than 5 percent, a third repetition was made. Three repetitions were made for the large samples.

To test the accuracy of the two machines with known volume samples, the Walloon Agricultural Research Centre conducted the volume measurements on 56 different samples. Different defined shapes with smooth surfaces and known volumes were produced and measured using in the devices. For the smaller device, 10 cubic shaped samples $\left(8.1\right.$ to $\left.263 \mathrm{~cm}^{3}\right), 10$ cylindrical shaped samples ( 3.4 to $279 \mathrm{~cm}^{3}$ ) and 10 parallelepiped shaped samples (16.7 to 184 $\mathrm{cm}^{3}$ ) were processed in 5 replications. For the larger device, the 8 cubic shaped samples (126 to $700 \mathrm{~cm}^{3}$ ), 9 cylindrical shaped samples (30 to $1127 \mathrm{~cm}^{3}$ ) and 10 parallelepiped shaped samples $\left(91.6\right.$ to $\left.310 \mathrm{~cm}^{3}\right)$ were processed in 5 replications.

To evaluate the influence of each tested method on the wood sample density results, individual and global mean values, we calculated mean WSG and two measures of dispersion, the standard deviation and coefficient of variation of the WSG values (Wiemann \& Williamson 2002). To compare the mean values of WSG obtained by the different methods, ANOVA were conducted at a significance level of 5 percent. A one-way ANOVA procedure was used for pair-wise multiple comparisons. The agreements between the chosen "preferred" method and other methods were evaluated using the coefficient of determination $\left(r^{2}\right)$ and the Fstatistical test for bias, slope $=1$ and intercept $=0$ using SAS software (Mayer \& Butler 1993, Leroy et al. 2007).

\section{Results and discussion}

Tab. 1 shows the mean densities $\left(\mathrm{g} / \mathrm{cm}^{3}\right)$ and density ranges $\left(\mathrm{g} / \mathrm{cm}^{3}\right)$ for the measured wood samples. The sand method was only used for the 100 small samples. It appears to 
Tab. 1 - Summary table of mean densities $\pm \mathrm{SE}\left(\mathrm{g} / \mathrm{cm}^{3}\right)$ and density ranges $\left(\mathrm{g} / \mathrm{cm}^{3}\right)$.

\begin{tabular}{|c|c|c|c|c|c|c|}
\hline \multirow{2}{*}{ Method } & \multicolumn{2}{|c|}{$\begin{array}{l}100 \text { small } \\
\text { samples }\end{array}$} & \multicolumn{2}{|c|}{$\begin{array}{l}18 \text { large } \\
\text { samples }\end{array}$} & \multicolumn{2}{|c|}{$\begin{array}{l}\text { Combination of } \\
\text { samples (118) }\end{array}$} \\
\hline & $\begin{array}{c}\text { Mean } \\
\text { density }\end{array}$ & $\begin{array}{c}\text { Density } \\
\text { range }\end{array}$ & $\begin{array}{c}\text { Mean } \\
\text { density }\end{array}$ & $\begin{array}{c}\text { Density } \\
\text { range }\end{array}$ & $\begin{array}{c}\text { Mean } \\
\text { density }\end{array}$ & $\begin{array}{c}\text { Density } \\
\text { range }\end{array}$ \\
\hline $\begin{array}{l}\text { Sand } \\
\text { (solid displacement) }\end{array}$ & $0.79 \pm 0.24$ & $0.22 \div 1.62$ & - & - & - & - \\
\hline $\begin{array}{l}\text { Glass micro-beads } \\
\text { (solid displacement) }\end{array}$ & $0.65 \pm 0.18$ & $0.16 \div 0.98$ & $0.62 \pm 0.22$ & $0.24 \div 1.12$ & $0.65 \pm 0.18$ & $0.16 \div 1.12$ \\
\hline $\begin{array}{l}\text { Wrapped in laboratory parafilm } \\
\text { (hydrostatic) }\end{array}$ & $0.65 \pm 0.17$ & $0.17 \div 0.97$ & $0.64 \pm 0.20$ & $0.29 \div 1.04$ & $0.65 \pm 0.17$ & $0.17 \div 1.04$ \\
\hline $\begin{array}{l}\text { Not wrapped in laboratory parafilm and not correcting } \\
\text { for absorption (hydrostatic) }\end{array}$ & $0.70 \pm 0.18$ & $0.19 \div 1.04$ & $0.69 \pm 0.21$ & $0.30 \div 1.10$ & $0.70 \pm 0.19$ & $0.19 \div 1.10$ \\
\hline $\begin{array}{l}\text { Not wrapped in laboratory parafilm but accounting for } \\
\text { absorption (hydrostatic) }\end{array}$ & $0.71 \pm 0.19$ & $0.19 \div 1.08$ & $0.69 \pm 0.21$ & $0.30 \div 1.11$ & $0.70 \pm 0.19$ & $0.19 \div 1.11$ \\
\hline
\end{tabular}

overestimate mean density and the standard deviation is highest. On the other hand, the glass microbeads method appears to underestimate WSG. Besides the case for the 18 large samples, this underestimation is similar to the underestimation when using laboratory parafilm. With the glass microbeads, it might be that the compaction of the beads is insufficient, giving a higher volume for the samples. For the wood samples wrapped in parafilm the increased volume is most likely due to the trapping of air between the sample and the parafilm. The mean densities of the hydrostatic method correcting for absorption and the mean densities of the plain hydro- static method are very similar. The patterns described can be observed clearly when looking at a randomly chosen samples (Fig. 2).

Large standard deviations for the sand and glass microbeads method are observed (Fig. 2: S4, S5, S7, S9, S10, S13, S14, S15 and S16). Assuming that the samples did not fall into the same position within the glass cylinders at each repetition, perhaps the sand particles and glass microbeads could not compact around the sample in the same manner, explaining the larger variation.

We performed an ANOVA on three sets of data: (1) 100 small samples; (2) the 18 large samples; and (3) the small and large samples put together (see below).

1. Small samples: the method has a significant effect on the estimation of density ( $p$ $<0.01$ ). The Levene statistics test rejects the null hypothesis that the group variances are equal $(\mathrm{p}>0.05)$. Using Tamhanes' test which does not assume equal variances, for the small samples, we find that there is a significant difference between the glass microbeads method and the sand method $(\mathrm{p}<0.01)$, the sand method and the hydrostatic parafilm method $(p<0.01)$ and between the sand method and the hydrostatic method $(\mathrm{p}<0.05)$;

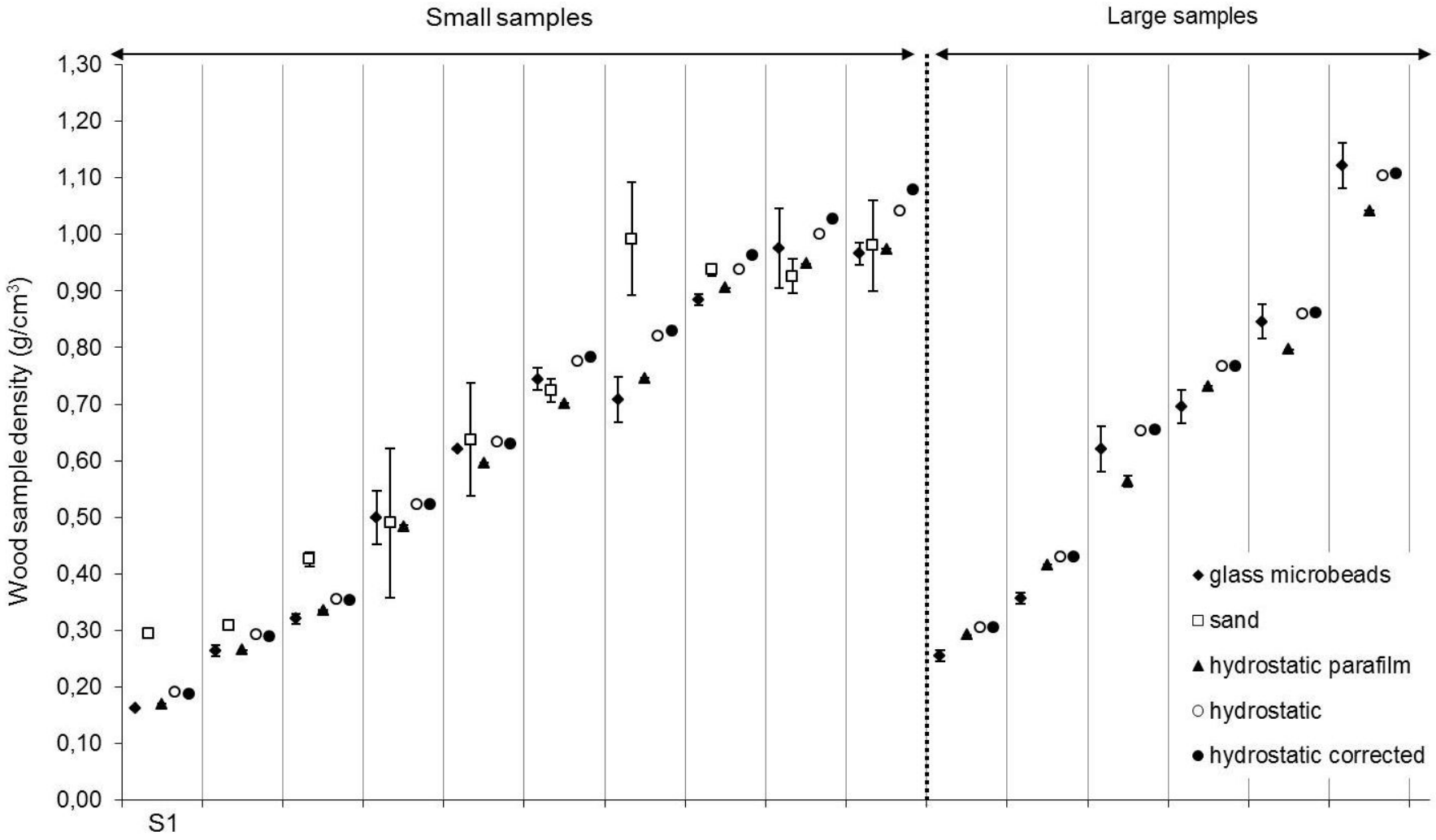

Fig. 2 - Wood sample density for 10 small samples and 6 large samples estimated by five different methods. The $y$-axis shows the wood specific gravity of a sample depending on the method used. Each column on the $x$-axis represents the WSG values for one sample. The sand method is only used for the small samples. Error bars show the standard deviation. S1 stands for sample 1 and so on. 


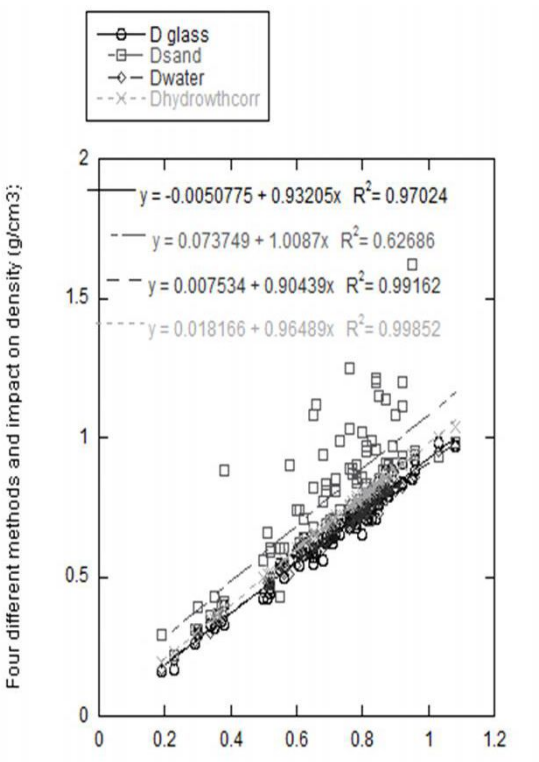

Wood specific gravity $(\mathrm{g} / \mathrm{cm} 3)$ measured with the preferred method (A)
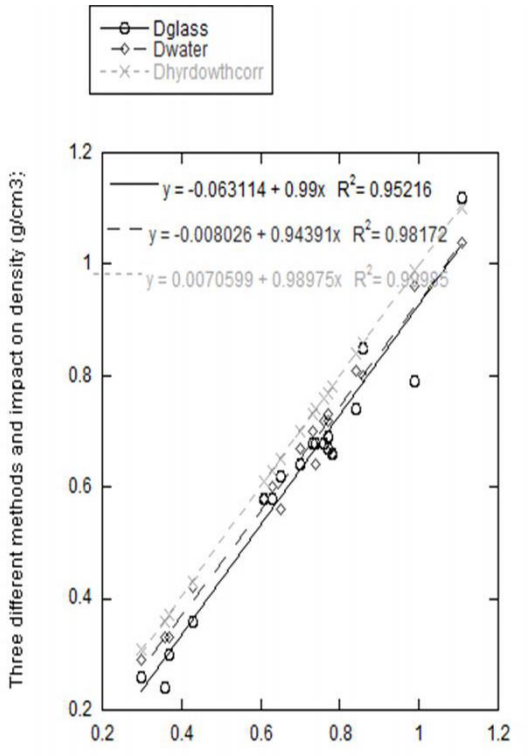

Wood specific gravity $(\mathrm{g} / \mathrm{cm} 3)$ measured with the preferred method (B)
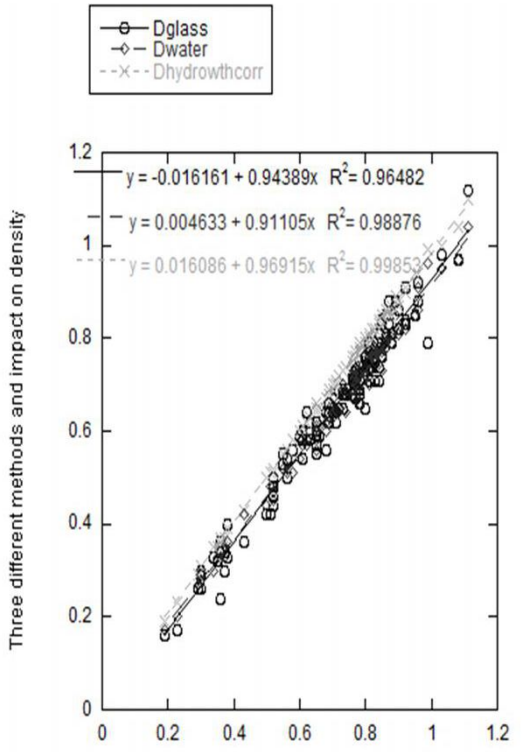

Wood specific gravity $(\mathrm{g} / \mathrm{cm} 3)$ measured with the preferred method

(C)

Fig. 3 - Regression analyses comparing the "preferred method" (hydrostatic method without parafilm wrapping but with correction to take account of water absorption) to the other different tested methods: (A) for 100 measured small samples, (B) for 18 measured large samples and $(\mathrm{C})$ for all measured samples.

2. Large samples: the choice of method has no significant effect on the mean density ( $\mathrm{p}$ $>0.05$ ). The Levene statistics test rejects the null hypothesis that the group variances are equal $(\mathrm{p}>0.05)$. Using Tamhanes' statistic, we find that there is no significant difference between the groups on mean density. Indeed, it appears that the sand method used on the small samples was the most problematic;

3. Combined: we find that choice of method has a slight but significant effect on the mean density $(\mathrm{p}<0.02)$. The Levene statistics test rejects the null hypothesis that the group variances are equal $(\mathrm{p}>0.05)$. Using Tamhanes' statistic, we find that there is no significant difference between the groups on mean density.

Regarding the hydrostatic method for samples not wrapped in parafilm but re- weighing after each measurement (correcting for absorption), there is an increase in volume for the samples when absorption is taken into account. There is an average volume increase of 0.61 percent for small samples and 0.29 percent for large samples. This has an impact of 0.61 percent on the mean density of the small samples and 0.29 percent for the large samples, affecting the mean density by the same amounts. This percentage can be regarded as negligible meaning that either hydrostatic method with samples not wrapped in parafilm could be a "preferred" choice of method. Not wrapping the samples in parafilm but correcting for absorption was chosen as the "preferred" method based on its precision and comprehensive approach for this study. However, this choice should be evaluated for each study and could, for example, be ranked on an assessment of an allowable error for the WSG measurement.

All subsequent regression analyses use the "preferred" method against which the other four methods are tested (Fig. 3 and Tab. 2). The relationships between the preferred method and other methods were satisfactory for all methods excluding the sand method. For the small samples, the large samples and the small and large samples combined, the coefficient of determination for: (a) the hydrostatic method (without parafilm or correction for absorption), (b) the hydrostatic method with parafilm, and (c) the glass microbeads method is highly significant $\left(r^{2}>0.95\right.$ in all cases). Hence, any of these three other methods are valid depending on the limitations of the samples to be worked with. However, the simultaneous F-test for bias, slope $=1$ and intercept $=0$ was significant for all methods and small, large or combined

Tab. 2 - Statistical summary of linear regression $(F$-statistic $)$ of the preferred method against the other methods. Slope $\mathrm{H}_{0}=1$, intercept $\mathrm{H}_{0}=$ $0 ;\left(^{*}\right): \mathrm{p}<0.05 ;\left(^{* *}\right): \mathrm{p}<0.01 ;(* * *): \mathrm{p}<0.001$.

\begin{tabular}{|c|c|c|c|c|c|c|c|c|c|c|}
\hline \multirow{2}{*}{$\begin{array}{l}\text { Preferred method } \\
\text { Linear regression }\end{array}$} & \multirow{2}{*}{$\begin{array}{c}\text { Sand } \\
100 \text { small } \\
\text { samples }\end{array}$} & \multicolumn{3}{|c|}{ Glass micro-beads } & \multicolumn{3}{|c|}{$\begin{array}{c}\text { Wrapped in laboratory } \\
\text { parafilm }\end{array}$} & \multicolumn{3}{|c|}{$\begin{array}{l}\text { Not wrapped in laboratory } \\
\text { parafilm and not correcting } \\
\text { for absorption }\end{array}$} \\
\hline & & $\begin{array}{c}100 \text { small } \\
\text { samples }\end{array}$ & $\begin{array}{l}18 \text { large } \\
\text { samples }\end{array}$ & combined & $\begin{array}{c}100 \text { small } \\
\text { samples }\end{array}$ & & combined & & & combined \\
\hline Adjusted $\mathrm{R}^{2}$ & 0.63 & 0.97 & 0.95 & 0.96 & 0.99 & 0.98 & 0.99 & 1 & 1 & 1 \\
\hline Slope & $\begin{array}{l}0.62 * * * \\
\pm 0.05\end{array}$ & & $\begin{array}{l}0.96 \\
\pm 0.05\end{array}$ & $\begin{array}{l}1.02 \\
\pm 0.02\end{array}$ & & & & $\begin{array}{l}3 * * * \\
0\end{array}$ & & $\begin{array}{l}3^{* * * *} \\
.0\end{array}$ \\
\hline Intercept & $\begin{array}{l}0.22 * * * \\
\pm 0.04\end{array}$ & $\begin{array}{l}0.03^{*} \\
\pm 0.01\end{array}$ & $\begin{array}{l}0.1^{*} \\
\pm 0.04\end{array}$ & $\begin{array}{l}0.04 * * * \\
\pm 0.01\end{array}$ & $\begin{array}{l}-0.00 \\
\pm 0.01\end{array}$ & $\begin{array}{l}0.02 \\
\pm 0.02\end{array}$ & $\begin{array}{l}0.0 \\
\pm 0.01\end{array}$ & $\begin{array}{l}-0.02 * * * \\
\pm 0.0\end{array}$ & $\begin{array}{l}-0.0 \\
\pm 0.0\end{array}$ & $\begin{array}{l}-0.01 * * * \\
\pm 0.0\end{array}$ \\
\hline Bias & $55.35 * * *$ & $140.46^{* * *}$ & $19.63 * * *$ & $144.82 * * *$ & $700.52 * * *$ & $21.35^{* * *}$ & $525.06 * * *$ & $100.48 * * *$ & 2.2 & $77.69 * * *$ \\
\hline$\%$ under or overestimation & $38 \%$ & $-4 \%$ & $4 \%$ & $-2 \%$ & $-10 \%$ & $-4 \%$ & $-9 \%$ & $-3 \%$ & (none) & $-3 \%$ \\
\hline
\end{tabular}




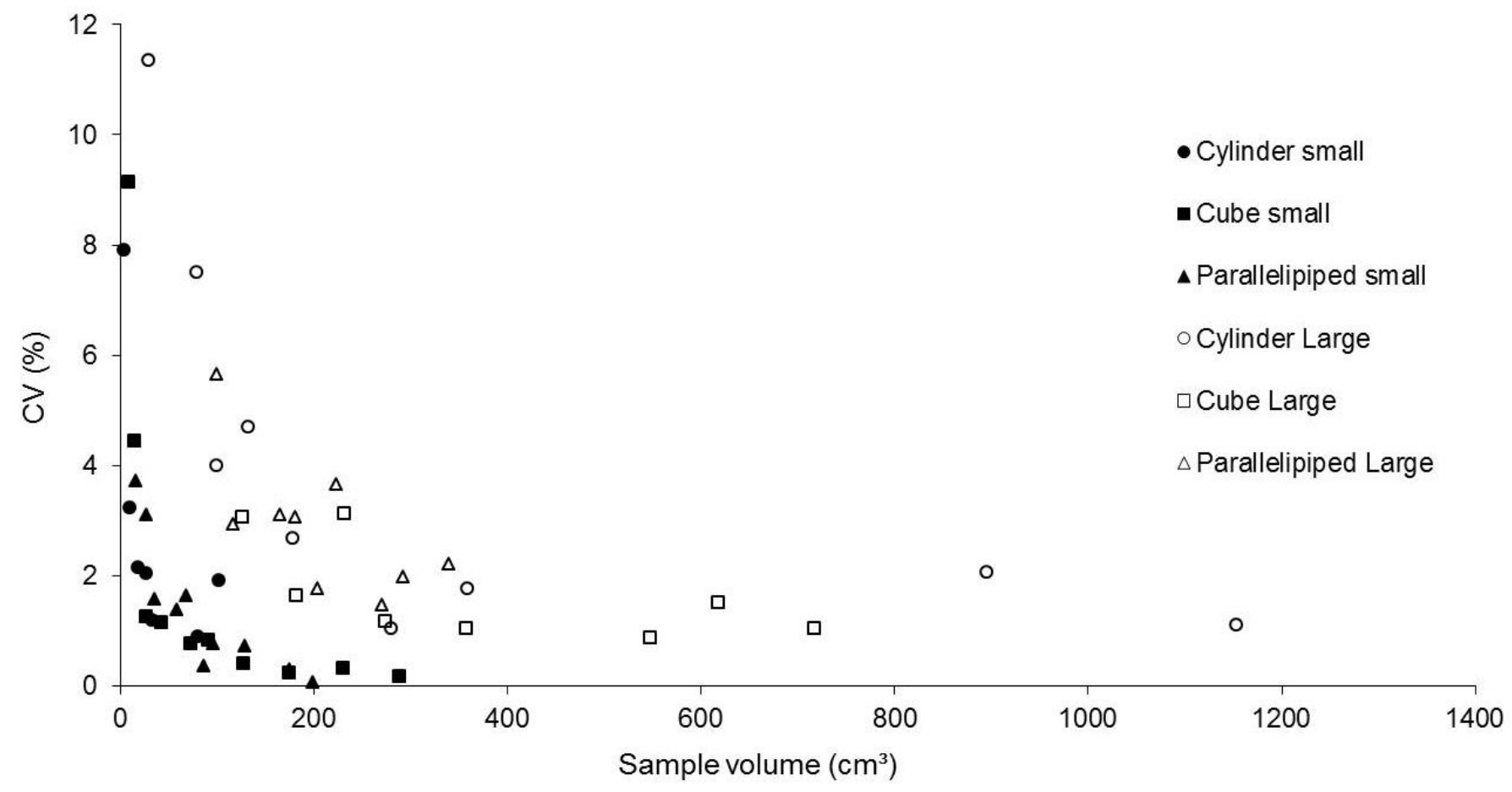

Fig. 4 - Measurements for the coefficient of variation (5 repetitions) for two devices (small and large) as a function of the sample volume.

samples $(\mathrm{p}<0.001)$ but one: the 18 large samples not wrapped in laboratory parafilm. The slope was significantly different from 1 for sand - 100 small samples; glass microbeads - 100 small samples; not wrapped in laboratory parafilm - 100 small samples and combined. The intercept was significantly different from 0 for sand; all three categories of samples for glass microbeads; not wrapped in laboratory parafilm - 100 small samples and combined.

The analysis of the coefficient of variation shows that the shape of the sample did not influence the precision of the method (Fig. 4). On the other hand, it is clear that the coefficient of variation is higher for lower volumes. Moreover, the variation is higher for the larger device, compared to the small one. In order to improve the precision of the method it is advisable (Tab. 3) to avoid the use of small samples. The relative accuracy of the method improved from 2.30 percent (all tested samples) to 1.29 percent (sample volume $>20 \mathrm{~cm}^{3}$ ) for the small device and from 3.60 percent (all tested samples) to
2.74 percent (sample volume $>100 \mathrm{~cm}^{3}$ ) for the larger device.

\section{Preliminary ecological application}

We provide a preliminary ecological assessment of the data collected. The WSG of the samples was measured using the preferred method. Tab. 4 provides a summary of the WSG values for each of the 53 species and compares the measured values to the values found in the GWDD (Zanne et al. 2009). For the species where a comparison of the averages could be made between the measured means and the means derived from the GWDD, there exists a significant difference between the means $(\mathrm{p}<0.05-$ indicated in Tab. 4 with an asterisk).

Where two or more species in a genus are present in our dataset, genus-level WSG averages were calculated (Tab. 5). Although this dataset is not as extensive, our data indicates that the four genus-level WSG averages can be considered as representative of their species-level WSG averages (the genus effect is significant at $p<0.01$ ) for Central Africa,

Tab. 3 - Precision of the different sample sizes and glass microbeads devices used.

\begin{tabular}{lccc}
\hline \multicolumn{1}{c}{ Method } & Avg. STD & Avg. CV (\%) & $\begin{array}{c}\text { Accuracy dr } \\
\text { for N = 5 (\%) }\end{array}$ \\
\hline Small device/All samples & 0.78 & 1.85 & 2.30 \\
$\begin{array}{l}\text { Small device / sample volume }>20 \\
\mathrm{~cm}^{3}\end{array}$ & 0.84 & 1.04 & 1.29 \\
$\begin{array}{l}\text { Large device / All samples } \\
\begin{array}{l}\text { Large device / Sample volume } \\
100 \mathrm{~cm}^{3}\end{array}\end{array}$ & 6.00 & 2.90 & 3.60 \\
\hline
\end{tabular}

similar to what Baker et al. (2004) observe in Amazonia.

We observe a considerable variation in WSG within many species (Fig. 5). However, it is important to highlight that although some xylarium samples include information on tree location (with variable accuracy), the position in the tree from which the sample was drawn is not available. As it is well known that wood density can vary substantially within, as well as between trees (Zobel \& van Buijtenen 1989), this might partially explain the large variations in some species. Furthermore, marked variations in WSG may be observed for a tree species which are attributable to differences in site quality and/or forest types (Patiño et al. 2009) and site specific differences have been observed comparing the same species growing in different site conditions or forest types (e.g., Nogueira et al. 2005, Nogueira et al. 2007).

\section{Conclusion}

The purpose of this paper was to: (1) highlight the potential use of xylarium samples to measure WSG; (2) provide an assessment on determining wood sample volume to calculate WSG from dry xylarium samples that have to be preserved in their original state; and (3) contribute and compare the WSG values of the 53 measured species in the Congo Basin Forest to existing databases and present a preliminary ecological assessment of the interindividual variation in WSG and the representativeness of genus-level averages compared to species-level averages. 
Tab. 4 - WSG of the measured samples per species compared to the WSG values in the GWDD. WSG values from the GWDD were taken for species occurring in Africa, as the measured species all originate from Central Africa. An asterisk $\left(^{*}\right)$ next to a species name indicates a significant difference $(\mathrm{p}<0.05)$ between the mean of the measured values and the mean of that species in the GWDD.

\begin{tabular}{|c|c|c|c|c|c|c|}
\hline Species & $\begin{array}{l}\text { No. Samples } \\
\text { measured }\end{array}$ & $\begin{array}{l}\text { Average WSG } \pm \\
\operatorname{STD}\left(\mathrm{g} / \mathrm{cm}^{3}\right)\end{array}$ & $\begin{array}{l}\text { Range WSG } \\
\qquad\left(\mathrm{g} / \mathrm{cm}^{3}\right)\end{array}$ & $\begin{array}{l}\text { No. values } \\
\text { given in } \\
\text { GWDD }\end{array}$ & $\begin{array}{c}\text { WSG value } \\
\text { GWDD } \pm \text { STD } \\
\left(\mathrm{g} / \mathrm{cm}^{3}\right)\end{array}$ & $\begin{array}{c}\text { WSG value } \\
\text { GWDD range } \\
\left(\mathrm{g} / \mathrm{cm}^{3}\right)\end{array}$ \\
\hline Albizia adianthifolia & 15 & $0.56 \pm 0.13$ & $0.38-0.86$ & 7 & $0.51 \pm 0.06$ & $0.45-0.65$ \\
\hline Albizia gummifera & 19 & $0.57 \pm 0.08$ & $0.43-0.71$ & 7 & $0.53 \pm 0.06$ & $0.47-0.65$ \\
\hline Alstonia congensis & 12 & $0.35 \pm 0.09$ & $0.27-0.62$ & 8 & $0.33 \pm 0.03$ & $0.29-0.39$ \\
\hline Autranella congolensis* & 20 & $0.88 \pm 0.09$ & $0.56-1.00$ & 9 & $0.75 \pm 0.11$ & $0.55-0.87$ \\
\hline Canarium schweinfurthii & 15 & $0.44 \pm 0.10$ & $0.22-0.57$ & 16 & $0.41 \pm 0.06$ & $0.30-0.55$ \\
\hline Ceiba pentandra & 10 & $0.30 \pm 0.06$ & $0.18-0.38$ & 14 & $0.28 \pm 0.03$ & $0.22-0.35$ \\
\hline $\begin{array}{l}\text { Chlorophora excelsa } \\
\text { (Milicia excelsa) }\end{array}$ & 48 & $0.57 \pm 0.07$ & $0.37-0.73$ & 24 & $0.58 \pm 0.06$ & $0.44-0.67$ \\
\hline Dacryodes edulis & 11 & $0.62 \pm 0.17$ & $0.50-0.94$ & 3 & $0.52 \pm 0.02$ & $0.50-0.53$ \\
\hline Diospyros crassiflora* & 6 & $1.05 \pm 0.08$ & $0.91-1.14$ & 5 & $0.86 \pm 0.09$ & $0.77-0.99$ \\
\hline Entandrophragma angolense* & 21 & $0.57 \pm 0.09$ & $0.44-0.80$ & 15 & $0.48 \pm 0.04$ & $0.44-0.59$ \\
\hline Entandrophragma candollei & 23 & $0.58 \pm 0.10$ & $0.33-0.75$ & 10 & $0.57 \pm 0.07$ & $0.42-0.67$ \\
\hline Entandrophragma cylindricum & 24 & $0.60 \pm 0.05$ & $0.50-0.70$ & 16 & $0.57 \pm 0.04$ & $0.50-0.63$ \\
\hline Entandrophragma utile* & 17 & $0.59 \pm 0.06$ & $0.50-0.75$ & 18 & $0.54 \pm 0.04$ & $0.44-0.58$ \\
\hline Gilbertiodendron dewevrei* & 41 & $0.78 \pm 0.06$ & $0.64-0.87$ & 4 & $0.71 \pm 0.02$ & $0.68-0.73$ \\
\hline $\begin{array}{l}\text { Gossweilerodendron balsamiferum* } \\
\text { (Prioria balsamifera) }\end{array}$ & 32 & $0.48 \pm 0.08$ & $0.33-0.71$ & 9 & $0.41 \pm 0.04$ & $0.31-0.45$ \\
\hline Guarea cedrata* & 17 & $0.63 \pm 0.06$ & $0.55-0.78$ & 15 & $0.51 \pm 0.03$ & $0.46-0.59$ \\
\hline Guarea laurentii* & 15 & $0.63 \pm 0.05$ & $0.55-0.72$ & 3 & $0.56 \pm 0.02$ & $0.54-0.59$ \\
\hline Hallea stipulosa* & 21 & $0.56 \pm 0.10$ & $0.44-0.77$ & 7 & $0.48 \pm 0.03$ & $0.45-0.53$ \\
\hline Khaya anthotheca* & 19 & $0.54 \pm 0.07$ & $0.41-0.67$ & 11 & $0.49 \pm 0.04$ & $0.44-0.55$ \\
\hline Klainedoxa gabonensis & 17 & $0.87 \pm 0.16$ & $0.47-1.05$ & 12 & $0.93 \pm 0.10$ & $0.78-1.15$ \\
\hline Lovoa trichilioides* & 18 & $0.58 \pm 0.08$ & $0.47-0.77$ & 19 & $0.45 \pm 0.04$ & $0.39-0.53$ \\
\hline Maesopsis eminii & 8 & $0.44 \pm 0.16$ & $0.34-0.82$ & 3 & $0.40 \pm 0.02$ & $0.37-0.41$ \\
\hline Mammea africana* & 21 & $0.70 \pm 0.09$ & $0.44-0.85$ & 16 & $0.63 \pm 0.04$ & $0.57-0.71$ \\
\hline Millettia laurentii & 19 & $0.79 \pm 0.06$ & $0.67-0.90$ & 8 & $0.76 \pm 0.05$ & $0.72-0.88$ \\
\hline Morinda lucida & 14 & $0.60 \pm 0.06$ & $0.53-0.74$ & - & - & - \\
\hline Musanga cecropioides & 27 & $0.21 \pm 0.09$ & $0.13-0.46$ & 12 & $0.24 \pm 0.07$ & $0.16-0.39$ \\
\hline Myrianthus arboreus & 7 & $0.55 \pm 0.05$ & $0.47-0.60$ & - & - & - \\
\hline Nauclea diderrichii* & 19 & $0.71 \pm 0.04$ & $0.63-0.80$ & 22 & $0.68 \pm 0.04$ & $0.59-0.78$ \\
\hline $\begin{array}{l}\text { Ongokea klaineana } \\
\text { (Ongokea gore) }\end{array}$ & 29 & $0.76 \pm 0.08$ & $0.56-0.88$ & 10 & $0.75 \pm 0.04$ & $0.69-0.83$ \\
\hline Panda oleosa & 10 & $0.67 \pm 0.07$ & $0.57-0.81$ & 1 & 0.57 & - \\
\hline Pentaclethra eetveldeana & 15 & $0.73 \pm 0.13$ & $0.55-0.99$ & 1 & 0.66 & - \\
\hline Pentaclethra macrophylla & 15 & $0.80 \pm 0.18$ & $0.54-1.03$ & 9 & $0.84 \pm 0.07$ & $0.73-0.94$ \\
\hline Pericopsis elata* & 14 & $0.70 \pm 0.08$ & $0.60-0.87$ & 12 & $0.64 \pm 0.04$ & $0.57-0.71$ \\
\hline Petersianthus macrocarpus* & 45 & $0.73 \pm 0.09$ & $0.46-0.90$ & 10 & $0.68 \pm 0.06$ & $0.57-0.77$ \\
\hline Polyalthia suaveolens & 19 & $0.72 \pm 0.05$ & $0.61-0.82$ & 1 & 0.70 & - \\
\hline $\begin{array}{l}\text { Prioria oxyphylla } \\
\text { (Oxystigma oxyphyllum) }\end{array}$ & 16 & $0.60 \pm 0.06$ & $0.50-0.80$ & 4 & $0.57 \pm 0.05$ & $0.53-0.65$ \\
\hline Pterocarpus soyauxii* & 20 & $0.72 \pm 0.08$ & $0.52-0.86$ & 14 & $0.66 \pm 0.07$ & $0.57-0.81$ \\
\hline Pterocarpus tinctorius & 14 & $0.65 \pm 0.20$ & $0.31-0.90$ & - & - & - \\
\hline Ricinodendron heudelotii* & 14 & $0.26 \pm 0.08$ & $0.15-0.47$ & 5 & $0.21 \pm 0.02$ & $0.19-0.23$ \\
\hline Scorodophloeus zenkeri & 16 & $0.76 \pm 0.10$ & $0.45-0.87$ & 4 & $0.72 \pm 0.09$ & $0.60-0.81$ \\
\hline $\begin{array}{l}\text { Staudtia kamerunensis } \\
\text { (Staudtia stipitata) }\end{array}$ & 51 & $0.80 \pm 0.07$ & $0.61-0.94$ & 17 & $0.80 \pm 0.07$ & $0.65-0.92$ \\
\hline Strombosia grandifolia* & 16 & $0.75 \pm 0.05$ & $0.67-0.83$ & 6 & $0.82 \pm 0.06$ & $0.75-0.91$ \\
\hline Strombosiopsis tetrandra & 18 & $0.73 \pm 0.08$ & $0.51-0.89$ & 1 & 0.66 & - \\
\hline Symphonia globulifera* & 20 & $0.68 \pm 0.09$ & $0.51-0.84$ & 8 & $0.59 \pm 0.06$ & $0.46-0.65$ \\
\hline Syzygium guineense* & 6 & $0.71 \pm 0.08$ & $0.64-0.87$ & 3 & $0.61 \pm 0.04$ & $0.58-0.65$ \\
\hline Terminalia superba* & 15 & $0.54 \pm 0.11$ & $0.34-0.83$ & 57 & $0.46 \pm 0.06$ & $0.32-0.62$ \\
\hline Tetrorchidium didymostemon & 8 & $0.44 \pm 0.07$ & $0.32-0.55$ & 1 & 0.44 & - \\
\hline Treculia Africana & 6 & $0.67 \pm 0.07$ & $0.59-0.78$ & - & - & - \\
\hline $\begin{array}{l}\text { Trema orientalis } \\
\text { (Trema guineensis) }\end{array}$ & 20 & $0.51 \pm 0.15$ & $0.30-0.82$ & 1 & 0.42 & - \\
\hline Uapaca guineensis* & 9 & $0.71 \pm 0.07$ & $0.62-0.84$ & 7 & $0.61 \pm 0.07$ & $0.54-0.71$ \\
\hline Vitex madiensis & 6 & $0.55 \pm 0.09$ & $0.47-0.72$ & - & - & - \\
\hline Xylopia aethiopica & 21 & $0.59 \pm 0.10$ & $0.44-0.77$ & 2 & $0.44 \pm 0.11$ & $0.36-0.52$ \\
\hline $\begin{array}{l}\text { Zanthoxylum gilletii } \\
\text { (Fagara macrophylla) }\end{array}$ & 16 & $0.71 \pm 0.13$ & $0.49-0.96$ & 11 & $0.69 \pm 0.14$ & $0.47-0.87$ \\
\hline
\end{tabular}


Tab. 5 - Genus-level averages for four genera of the dataset.

\begin{tabular}{lcc}
\hline \multicolumn{1}{c}{ Genus } & $\begin{array}{c}\text { No. } \\
\text { samples }\end{array}$ & $\begin{array}{c}\text { Average WSG } \\
\pm \text { STD }\left(\mathbf{g} / \mathbf{c m}^{\mathbf{3}}\right)\end{array}$ \\
\hline Albizia & 34 & $0.57 \pm 0.11$ \\
Entandrophragma & 68 & $0.58 \pm 0.08$ \\
Pentaclethra & 30 & $0.77 \pm 0.16$ \\
Pterocarpus & 34 & $0.69 \pm 0.15$ \\
\hline
\end{tabular}

To estimate wood volume of xylarium samples to calculate WSG, we generallyrecommend the hydrostatic approach of not wrapping samples in laboratory parafilm. As the impact on WSG of correcting for absorption is negligible, this is not necessary. Comparing the hydrostatic method for samples not wrapped in parafilm but correcting for absorption to the other two hydrostatic methods (i.e., either with parafilm, or without parafilm but without correction for absorption) and the glass microbeads method resulted in a high $r^{2}$ value $(>0.95)$. This suggests that any of these other three methods are valid depending on the limitations of the samples one would be working with and the objectives of the study. Hence, we have shown the validity of using laboratory parafilm to wrap samples for the hydrostatic method and the glass microbeads construction. When samples cannot be immersed in water in any circumstances, the glass microbeads construction offers a reliable alternative. When possible, using sterile water instead of tap water may further increase the precision of the hydrostatic methods.

This study also illustrates the contribution that the measurement of xylarium samples can make to existing global wood density databases. This contribution consists both in adding species that are currently not present in the database, but also helping to improve the current database estimates by increasing the number of measurements. Although the data presented is by no means extensive, it does illustrate the intervariability in WSG within and between species and suggest that genus-level WSG averages may indeed be representative of species-level WSG averages in the Congo Basin.

In a broader context, we have illustrated that, although working with xylarium samples brings several methodological challenges, these can be overcome to enable the use of xylarium samples to calculate WSG. In this way, xylaria hold a great amount of untapped information on taxonomic, spatial and potentially temporal variation in wood specific gravity that could be useful for ecologists, especially for providing more robust estimates of aboveground biomass and understanding of forest dynamics.

\section{Acknowledgments}

We thank Pol Dricot for constructing the glass microbeads machines and the handling of samples for testing the accuracy of the glass microbeads method. We also thank Nicolas Barbier and three reviewers for helping us to improve the manuscript.

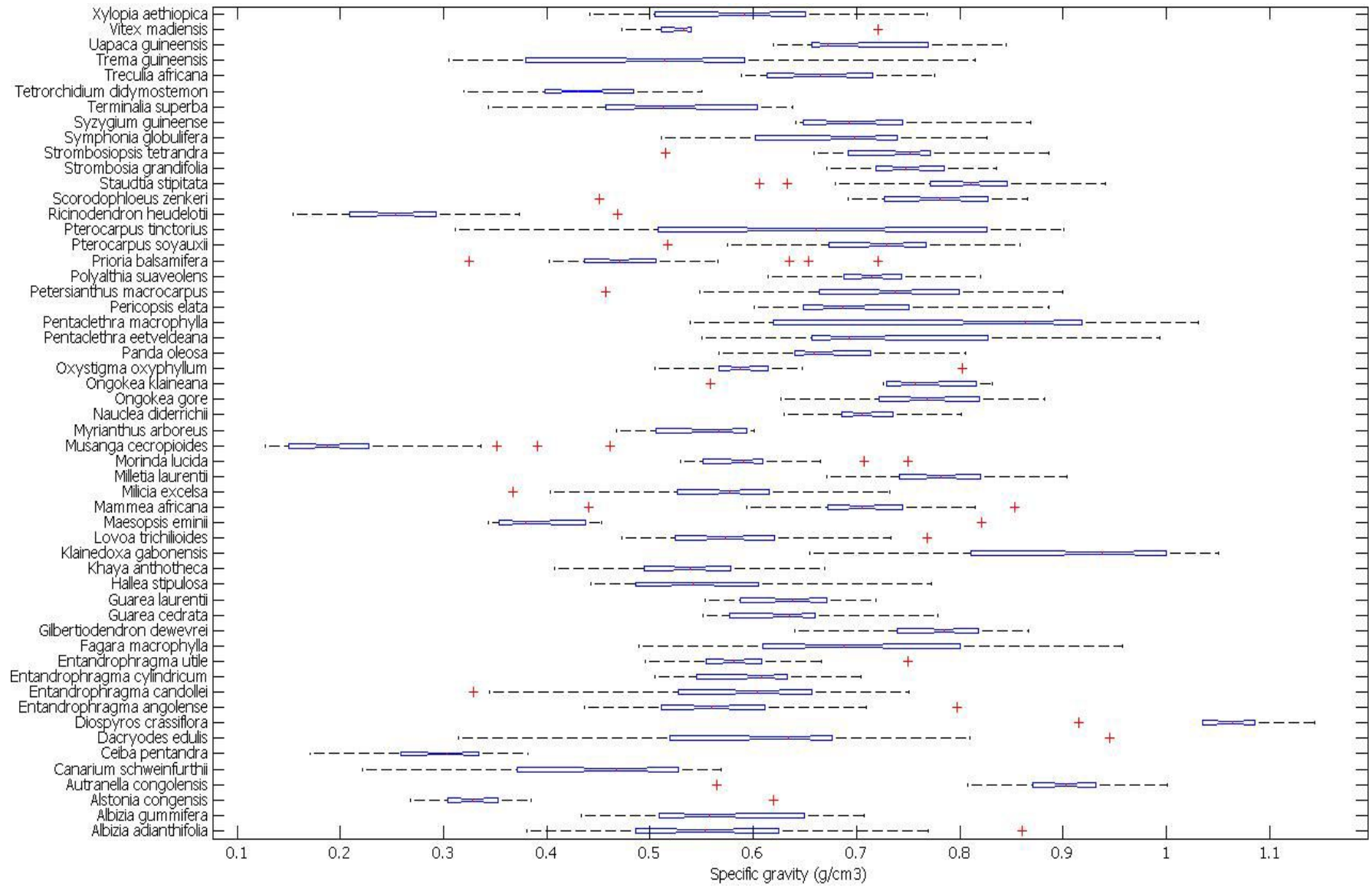

Fig. 5 - Boxplot showing the inter-individual variation in WSG for the 53 measured species. The boxplot also shows the notches for each species: two medians are significantly different at the 5 percent significance level if their intervals (interval endpoints are the extremes of the notches) do not overlap. The figure also shows the whiskers of which the length $w$ is set at 1.5. Points are drawn as outliers (crosses) if they are larger than $q_{3}+w\left(q_{3}-q_{1}\right)$ or smaller than $q_{1}-w\left(q_{3}-q_{1}\right)$, where $q_{1}$ and $q_{3}$ are the $25^{\text {th }}$ and $75^{\text {th }}$ percentiles, respectively. The whisker plotted on the figure extends to the adjacent value, which is the most extreme data value that is not an outlier. 


\section{References}

ASTM International (2011). ASTM D2395 07ae1 Standard test methods for specific gravity of wood and wood-based materials. Web page. [online] URL: http://www.astm.org/Standards/ D2395.htm

Baker TR, Philips OL, Malhi Y, Almeida S, Arroyo L, Di Fiore A, Erwin T, Killeen TJ, Susan G, Laurance SG, Laurance WF, Lewis SL, Lloyd J, Monteagudo A, Neill DA, Patiño S, Pitman NCA, Silva JNM, Vásquez Martínez R (2004). Variation in wood density determines spatial patterns in Amazonian forest plots. Global Change Biology 10: 1-18. - doi: 10.1111/j.1365-2486 2004.00751.x

Beeckman H (2008). A xylarium for the sustainable management of biodiversity: the wood collection of the royal museum for central Africa, Tervuren, Belgium. Le bulletin de l'APAD no. 26, Gestion des Ressources Naturelles. Participations et médiations. [online] URL: http://apad.revues.org/document3613.html

Beeckman H (2007). Wood. Collections of the Royal Museum for central Africa. Collections of the Royal Museum for Central Africa, Belgium, pp.112. [ISBN: 978-90-74752-17-6]

Bergsten U, Lindeberg J, Rindby A, Evans R (2001). Batch measurements of wood density on intact or prepared drill cores using $\mathrm{x}$-ray microdensitometry. Wood Science and Technology 35: 435-452. - doi: 10.1007/s002260100106

Cameron JF, Berry PF, Phillips EWJ (1959). The determination of wood density using beta rays Holzforschung 13: 78-84. - doi: 10.1515/hfsg 1959.13.3.78

Chave J, Andalo C, Brown S, Cairns MA, Chambers JQ, Eamus D, Fölster H, Fromard F, Higuchi N, Kira T, Lescure JP, Nelson BW, Ogawa H, Puig H, Riéra B, Yamakura T (2005). Tree allometry and improved estimation of carbon stocks and balance in tropical forests. Oecologia 145 (1): 87-99. - doi: 10.1007/s00442-005-0100$\mathrm{x}$

Dutilleul P, Herman M, Avella-Shawn T (1998), Growth rate effects among ring width, wood density, and mean tracheid length in Norway spruce (Picea abies). Canadian Journal of Forest Research 28: 56-68. - doi: 10.1139/x97-189

Fearnside PM (1997). Wood density for estimating forest biomass in the Brazilian Amazon. Forest Ecology and Management 90: 59-87. doi: 10.1016/S0378-1127(96)03840-6

Hacke UG, Sperry JS, Pittermann J (2000). Drought experience and cavitation resistance in six shrubs from the Great Basin, Utah. Basic and Applied Ecology 1 (1): 31-41. - doi: 10.1078/ 1439-1791-00006

Hacke UG, Sperry JS, Pockman WT, Davis SD, McCulloh KA (2001). Trends in wood density and structure are linked to prevention of xylem implosion by negative pressure. Oecologia 126: 457-461. - doi: 10.1007/s004420100628

Houghton R (2005). Tropical deforestation as a source of greenhouse-gas emissions. In: "Tropical deforestation and climate change" (Moutinho $\mathrm{P}$, Schwartzmann $\mathrm{S}$ eds). IPAM, Instituto de
Pesquisa Ambiental da Amazônia, Belém, Pará, Brazil - Environmental Defense, Washington DC, USA.

King DA, Davies SJ, Nur Supardi MN, Tan S (2005). Tree growth is related to light interception and wood density in two mixed dipterocarp forests of Malaysia. Functional Ecology 19: 445453. - doi: 10.1111/j.1365-2435.2005.00982.x

Kollmann F (1951). Technologie des holzes und der holzwerkstoffe. Zweite auflage. I. Band. Springer-Verlag, Berlin - Göttingen, Heidelberg Bergmann JF, München, pp. 1050.

Leroy C, Saint-André L, Auclair D (2007). Practical methods for non-destructive measurement of tree leaf area. Agroforestry Systems 71: 99108. - doi: 10.1007/s10457-007-9077-2

Lindgren LO (1991). The accuracy of medical CAT-scan images for non-destructive density measurements in small volume elements within solid wood. Wood Science and Technology 25 (6): 425-432. - doi: 10.1007/BF00225235

Mayer DG, Butler DG (1993). Statistical validation. Ecological Modelling 68 (1-2): 21-32. - doi: 10.1016/0304-3800(93)90105-2

Mothe F, Duchanois G, Zannier B, Leban JM (1998). Analyse microdensitométrique appliquée au bois: méthode de traitement des données utilisée à l'INRA-ERQB (programme CERD). Annales des Sciences Forestières 55 (3): 301-313. doi: 10.1051/forest:19980303

Muller-Landau HC (2004). Interspecific and intersite variation in wood specific gravity of tropical trees. Biotropica 36 (1): 20-32. - doi: 10.1111/ j.1744-7429.2004.tb00292.x

Nogueira EM, Nelson BW, Fearnside PM (2005). Wood density in dense forest in central Amazonia, Brazil. Forest Ecology and Management 208: 261-286. - doi: 10.1016/j.foreco.2004.12. 007

Nogueira EM, Fearnside PM, Nelson BW, França MB (2007). Wood density in Brazil's "arc of deforestation": implications for biomass and flux of carbon from land-use change in Amazonia, Brazil. Forest Ecology and Management 248: 119-135. - doi: 10.1016/j.foreco.2007.04.047

Nuopponen MH, Birch GM, Sykes RJ, Lee SJ, Stewart D (2006). Estimation of wood density and chemical composition by means of Diffuse Reflectance Mid-Infrared Fourier Transform (DRFT-MIR) spectroscopy. Journal of Agricultural and Food Chemistry 54: 34-40. - doi: 10.1021/jf051066m

Patiño S, Lloyd J, Paiva R, Baker TR, Quesada CA, Mercado LM, Schmerler J, Schwarz M, Santos AJ, Aguilar A, Czimczik CI, Gallo J, Horna V, Hoyos EJ, Jimenez EM, Palomino W, Peacock J, Peña-Cruz A, Sarmiento C, Sota A, Turriago JD, Villanueva $\mathrm{B}$, Vitzthum $\mathrm{P}$, Alvarez $\mathrm{E}$, Arroyo L, Baraloto C, Bonal D, Chave J, Costa AC, Herrera R, Higuchi N, Killeen T, Leal E, Luizão F, Meir P, Monteagudo A, Neil D, Núñez-Vargas P, Peñuela MC, Pitman N, Priante Filho N, Prieto A, Panfil SN, Rudas A, Salomão R, Silva N, Silveira M, Soares dealmeida S, Torres-Lezama A, Vásquez-Martínez R, Vieira I, Malhi Y, Phillips OL (2009). Branch xylem density variations across the Amazon Basin. Biogeosciences 6 (4): 545-568. - doi: 10.5194/ bg-6-545-2009

Pliura A, Zhang SY, MacKay J, Bousquet J (2007). Genotypic variation in wood density and growth traits of poplar hybrids at four clonal trials. Forest Ecology and Management 238: 92106. - doi: 10.1016/j.foreco.2006.09.082

Polge H (1966). Établissement des courbes de variation de la densité du bois par exploration densitométrique de radiographies d'échantillons prélevés à la tarière sur des arbres vivants - Applications dans les domaines technologique et physiologique. Ph.D. Dissertation, Université de Nancy-1, Champenoux, France, pp. 215.

Rabier F, Temmerman M, Böhm T, Hartmann H, Daugberg Jensen P, Rathbauer J, Carrasco J, Fernández M (2006). Particle density determination of pellets and briquettes. Biomass and Bioenergy 30: 954-963. - doi: 10.1016/j.biombioe.2006.06.006

Simpson W, TenWolde A (1999). Physical properties and moisture relations of wood. In: "Forest products laboratory. Wood handbook wood as an engineering material. Gen. Tech. Rep. FPL-GTR-113, Forest Products Laboratory, USDA Forest Service, Madison, WI, USA, pp. 463.

Simpson WT (1993). Specific gravity, moisture content, and density relationships for wood. Gen. Tech. Rep. FPL-GTR-76, Forest Products Laboratory, USDA Forest Service, Madison, WI, USA, pp. 13.

Slik JWF (2004). El Nino droughts and their effects on tree species composition and diversity in tropical rain forests. Oecologia 141: 114-120. doi: 10.1007/s00442-004-1635-y

Slik JW (2006). Estimating species-specific wood density from the genus average in Indonesian trees. Journal of Tropical Ecology 22 (04): 481. doi: $10.1017 / \mathrm{S} 0266467406003324$

Stern WL (1988). Index xylariorum. Institutional wood collections of the World 3. IAWA Bulletin 9: 203-252.

Via BK, Fasina O, Pan H (2011). Assessment of pine biomass density through mid-infrared spectroscopy and multivariate modeling. Bioresources 6: 807-822.

Via BK, So CL, Shupe TF, Stine M, Groom LH (2005). Ability of near infrared spectroscopy to monitor air-density density distribution and variation of wood. Wood Fiber Science 37: 394-402. [online] URL: http://swst.metapress.com/content/ct61tvt402421265/

Via BK, Shupe TF, Groom LH, Stine M, So CL (2003). Multivariate modelling of density, strength and stiffness from near infrared spectra for mature, juvenile and pith wood of longleaf pine (Pinus palustris). Journal of Near Infrared Spectroscopy 11: 365-378. - doi: 10.1255/jnirs. 388

Wiemann MC, Williamson GB (2002). Geographic variation in wood specific gravity: effects of latitude, temperature and precipitation. Wood and Fibre Science 34 (1): 96-107. [online] URL: http://swst.metapress.com/content/h3063364437 
nh100/

Zanne AE, Lopez-Gonzalez G, Coomes DA, Ilic J, Jansen S, Lewis SL, Miller RB, Swenson NG,
Wiemann MC, Chave J (2009). Global wood density database. Dryad. [online] URL: http://datadryad.org/handle/10255/dryad.235
Zobel BJ, van Buijtenen JP (1989). Wood variation: its causes and control. Springer-Verlag, Berlin, Germany. 